\title{
Antimicrobial effect of Siddha preparation Vazhai kizhangu neer and Amuri against common urinary pathogens
}

\author{
Research Article
}

\section{Sherin Nisha $\mathbf{A}^{1 *}$, Sivakkumar $\mathbf{S}^{2}$, Meenakumari $\mathbf{R}^{3}$}

\author{
1. PG Scholar, 2. Associate Professor, Department of Gunapadam, \\ 3 Head of the Department / Director, \\ National Institute of Siddha, Ministry of AYUSH, Chennai. India.
}

\begin{abstract}
Urinary tract infection (UTI) is an infection.It occurs in any part of the urinary tract mostly affects lower urinary tract which is common in women. Almost half of all women will experience UTI once during their lifetime. The elderly, patients with diabetes or multiple sclerosis, patients with acquired immunodeficiency syndrome/human immunodeficiency virus, patients with spinal cord injuries and/or catheters are at high risk for UTI. Resistance development, adverse reactions of antibiotics, and other problems lead to find out the alternative approaches like remedies from natural resources in controlling UTIs. This study is aimed to validate the anti-microbial effect of natural products VazhaiKizhangu Neer and Amuri obtained from plantain tree (Musa paradisiaca Linn.) which are used for UTI in siddha system. The both samples were subjected to antimicrobial activity by well diffusion method. The result shows that, the zone of inhibition (in mm) for VazhaiKizhangu Neer and Amuri against common urinary pathogens E.coli, Pseudomonas aeuriginosa, Proteus mirabilis and Klebsiella pneumoniae was 14, 15; 9, 11; 0, 12; 14,13 respectively. These results revealed that both samples are potentially effective in suppressing microbial growth of urinary pathogens. Comparatively, the Antimicrobial activity of Amuri was almost equal to VazhziKizhzngu Neer. This study may authenticate the usage of VazhaiKizhangu Neer and Amuri for the management of Urinary Tract Infections.
\end{abstract}

Key Words: Antimicrobial activity, Vazhai Kizhangu neer, Amuri, Siddha Medicine.

\section{Introduction}

The process of inhibition or destroying the growth of microbes is defined as antimicrobial activity. It may be antiviral, anti-bacterial, anti-fungal. They all have different way of action through which they act to overcome the infection. Preventing the multiplication of bacteria is via the antiseptics and disinfectant agents by collapsing the bacterial cell or bacterial conjugation. The widely using method for antimicrobial activity screening is well diffusion method for plants or microbial extracts. An infection of urinary system, kidneys, ureters, bladder and urethra is known as Urinary Tract Infection (UTI).It commonly targets the women. About half of women experienced UTI at some time during their life (1).Both Gram-negative and Gram-positive bacteria cause urinary tract infections, and also by certain fungi. Most urinary tract infections are caused by bacteria E. coli. Others include staphylococcus, proteus, klebsiella pneumoniae,

* Corresponding Author:

\section{Sherin Nisha A}

Department of Gunapadam,

National Institute of Siddha,

Ministry of AYUSH,

Chennai - 600047. India.

Email Id: sherin9664@gmail.com enterococcus and candida. Antibiotics remain the centrepiece of treatment in acute UTI; In Siddha system also, many drugs, formulations and extracts have been used as remedy for Urinary Tract Infections (UTI). They are Vazhai kattai neer (Amuri),Vazhai kizhangu neer, Pani neer, Nanaari ooral neer, etc. Amuri is signified as an elixir of life as it has the property of rejuvenation (Kayakarpam or Kayakalpam).Some of the name that represent Amuri in siddha literature, they are Pazhzcharu, Aagasa kangai, Suthasalam, Pugai neer, Kaadi neer, Naatha neer, Sivambu, Sivaambu, Kalpam, Sivaneer, Siruneer, Panineer, Ilaneer, Pazhaya sotru neer, Elumichai charu, Rishaba neer, Chandra pushpakarani neer, Soma neer, Piraineer, Mathipaal, Soma banam, Soma rasa panam, etc (2). Amuri preparation methods are concealed by Siddhars and highly preserved because of its importance in Siddha medical system.An unpublished manuscript Kandarnaadi vaakiyam, expresses that Amuri is prepared from banana tree. In this method, Amuri is prepared by keeping the Guru chunnam inside the banana tree (3). In siddha literature, there are many school of thoughts in the finding and preparation of Amuri. According to Gunapadam Mooligai Siddha text book, Vazhai kizhangu neer is an extracted juice obtained from a pit made in the stump of the plantain tree. The liquid accumulate in it which is indicated for urinary tract infections, ascites, anemia and acid peptic diseases (4). The present study is aimed to validate the 
Sherin Nisha A et.al., Antimicrobial effect of Siddha preparation Vazhai kizhangu neer and Amuri against common urinary pathogens

antimicrobial activity of traditional Siddha preparation Amuri (an elixir from Plantain tree) and Vazhai Kizhangu neer against common urinary pathogens.

\section{Materials and Methods}

\section{Preparation of Guru Chunnam}

Ingredients

- Thurusu (Copper sulphate) - 300 gm

- Sangu (Conch Shell) - 250 gm

The above ingredients were purchased from reputed raw drug store Gopala Aasan store, Nagercoil, Tamilnadu, India and authenticated by Gunapadam experts, Department of Gunapadam, National Institue of Siddha, Tambaram Sanatorium, Chennai.

\section{Method of Preparation}

Sangu (Conch Shell 250gm) was purified by soaking in Lemon juice for one day (24 hours) and washed with water. After drying, it was collected and subjected into traditional Pudam (calcination) process with 100 numbers of cow dung cakes. After that it was grounded well in stone mortar to become a fine powder (Sangu parpam). Purified Thurusu (Copper sulphate 300gm) was mixed with Sangu parpam and grounded well with lemon juice for $3 \mathrm{hrs}$ and subjected to pudam process with 50 numbers of cow dung cakes. The Guru chunnam was collected and stored in an air tight container for the study.

\section{Preparation of Amuri}

Well grown banana tree was selected just before flowering. On the $10^{\text {th }}$ lunar day a window was cut open in the neck region of the tree by cutting of small rectangular sheath layers to a depth to reach a trunk core. Three teaspoon full of Guru Chunnam (30gm) was kept inside the window and the slice was placed back and tied (Fig.no.1, 2, 3, 4). The tree was irrigated. After 5 days, on the day of full moon the tree was cut off $30 \mathrm{~cm}$ from the ground level. The cross section of the stump was scooped to create a cup like hollow. A small hole was drilled and rubber tube is inserted. An elixir was collected continuously for 5 days (Fig.no. 5). The collected amuri was used for the study (Sample-A) (Fig.no: 8).

Fig.no: 1, 2. Cutting of rectangular sheath in the trunk of plantain tree and placing of Guru Chunnam
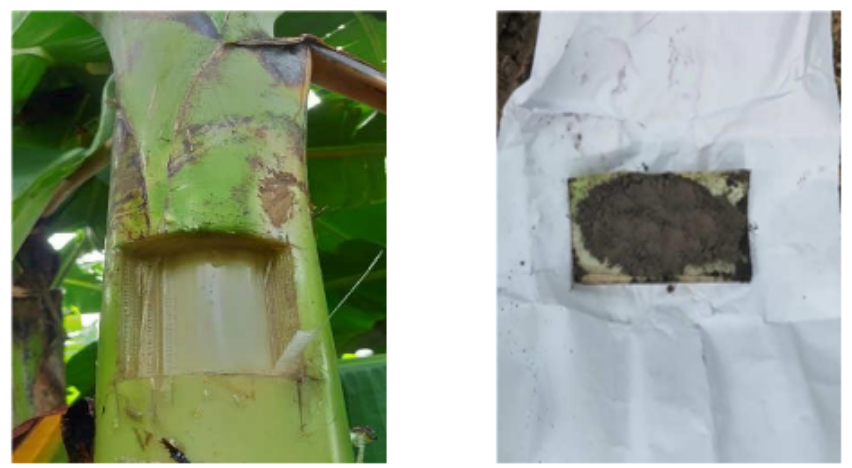

Fig.no: 3, 4. Implantation of Guru chunnam inside the plantain tree.
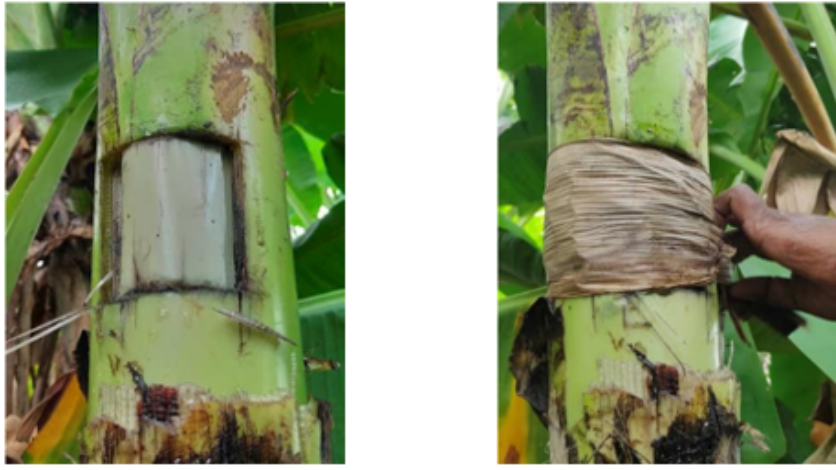

Fig.no: 5. Collection of Amuri from plantain tree.

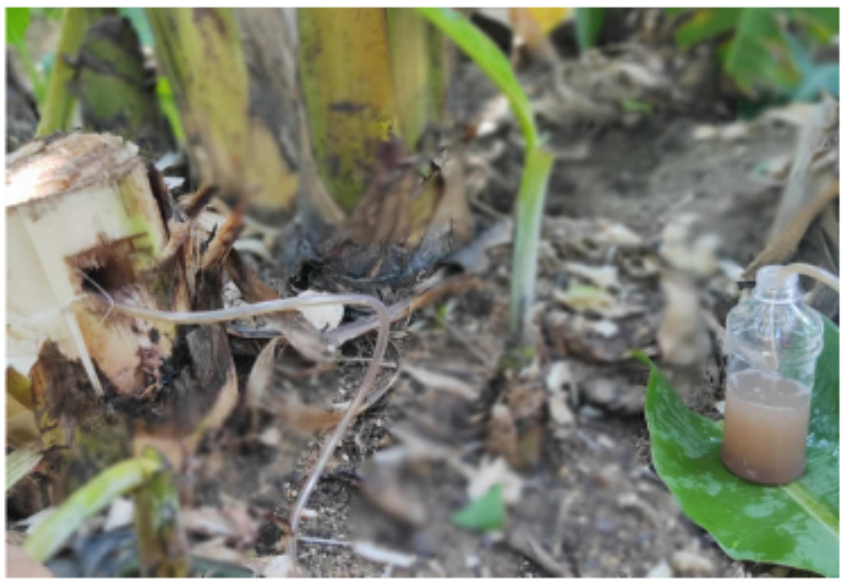

\section{Preparation of Vazhai kizhangu Neer}

A pit was made in the stump of the plantain tree left it for a whole night. The next day the accumulated fluid was collected (Fig.no: 6, 7) and secured in a glass bottle for the study (Sample-B) (Fig.no: 9).

Fig.no: 6, 7. Making pit in the Stump of the plantain tree and Collection of Vazhai kizhangu neer

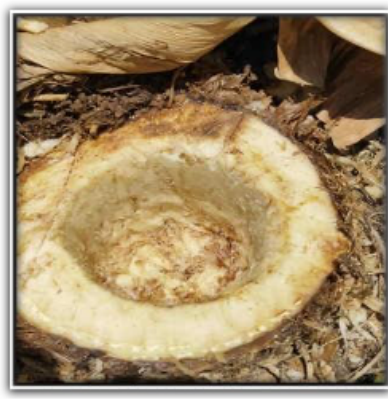

Fig.no: 8. Amuri

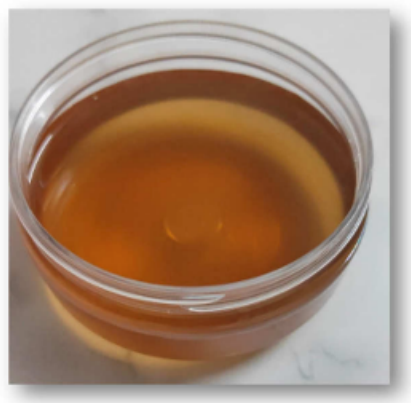

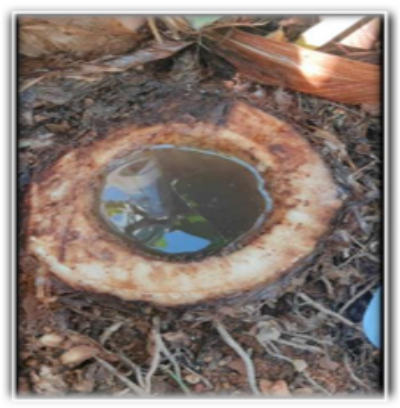

Fig.no: 9. Vazhai kizhangu neer

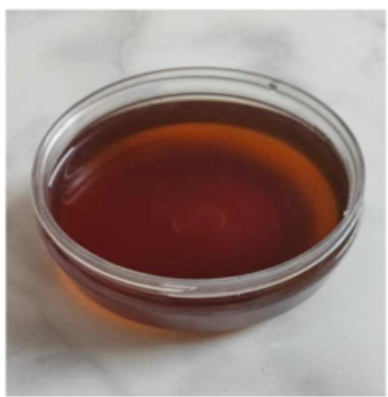


Antimicrobial Activity (5)

The antimicrobial study was performed by using well diffusion method for both samples of Amuri (Sample-A) and Vazhai kizhangu Neer (Sample-B). The following strains E.coli, Proteus mirabilis, Pseudomonas aeuriginosa and Klebsiella pneumoniae were used for the study and maintained in good laboratory condition.

\section{Preparation of inoculum}

The extract of study drugs were sterilized in flask, cooled to $450-500{ }^{\circ} \mathrm{C}$ and then poured into sterilized petriplates. The prepared MHA (Muller Hinton agar) was inoculated into the well in graded concentration $(250,500,1000,2000 \mu \mathrm{g} / \mathrm{ml})$ using sterile syringe. The plates inoculated with bacteria will be incubated at $370^{\circ} \mathrm{C}$ for 24 hours. The diameter of the inhibited zone was measured in $\mathrm{mm}$. The results were compared with standard drug Chloramphenicol $(10 \mu \mathrm{g})$.

\section{Well- diffusion method}

The antibacterial activities of the sample A and Sample B were carried out by well diffusion method. The concentrations of the test compounds were used at the concentration of $250,500,1000$ and $2000 \mu \mathrm{g} / \mathrm{ml}$. The microorganisms were cultured using MuellerHinton broth (MHB). After 24 hours, adjusted to standard sub culture dilution. The Muller Hinton Agar (MHA) medium inoculated petri dishes were cultured with diluted bacterial strain. Cylinder with $6 \mathrm{~mm}$ diameter is created aseptically with a sterile cork borer. Each concentration was inoculated into the cylinder. Standard drug Chloramphenicol $(10 \mu \mathrm{g})$ was used as a positive reference standard to determine the sensitivity of each microbial species tested. Then the inoculated plates were incubated at $37^{\circ} \mathrm{C}$ for $24 \mathrm{~h}$. The clear zone around the disc's diameter was measured in millimeters as its anti- microbial.

\section{Results \& Discussion}

The anti-bacterial activity against common urinary pathogens has been studied for study drug Amuri (sample - A) and Vazhai kizhangu neer (sample B). The results were tabulated in Table. no: 1,2. Table no: 1. Anti-bacterial activity of Amuri- Zone of Inhibition (mm)

Table no: 1. Anti-bacterial activity of Amuri-Zone of Inhibition (mm)

\begin{tabular}{|c|c|c|c|}
\hline $\begin{array}{l}\text { Bacterial } \\
\text { Strains }\end{array}$ & $\begin{array}{l}\text { Concentr } \\
\text { ation }\end{array}$ & $\begin{array}{c}\text { Sample A } \\
\text { (Amuri) }\end{array}$ & $\begin{array}{c}\text { Chloramp } \\
\text { henicol } \\
(10 \mu \mathrm{g})\end{array}$ \\
\hline E.Coli & $1000 \mu \mathrm{g}$ & $\frac{-}{15}$ & 17 \\
\hline 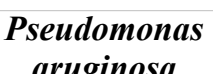 & $1000 \mu \mathrm{g}$ & - & 12 \\
\hline $\begin{array}{c}\text { aruginosa } \\
\text { Proteus } \\
\text { mirabilis }\end{array}$ & $\begin{array}{l}2000 \mu \mathrm{g} \\
1000 \mu \mathrm{g} \\
2000 \mu \mathrm{g}\end{array}$ & $\begin{array}{l}11 \\
10 \\
12\end{array}$ & 14 \\
\hline $\begin{array}{c}\text { Klebsiella } \\
\text { pnemoniae }\end{array}$ & $\begin{array}{l}1000 \mu \mathrm{g} \\
2000 \mu \mathrm{g}\end{array}$ & $\begin{array}{c}9 \\
13\end{array}$ & 12 \\
\hline
\end{tabular}

The result shows that, the zone of inhibition for Amuri against common urinary pathogens are E.coli $15 \mathrm{~mm}$, Pseudomonas aeuriginosa $11 \mathrm{~mm}$, Proteus mirabilis $12 \mathrm{~mm}$ and Klebsiella pneumoniae $13 \mathrm{~mm}$, whereas Vazhai Kizhangu Neer, E.coli 14mm, Pseudomonas aeuriginosa $9 \mathrm{~mm}$, and Klebsiella $14 \mathrm{~mm}$ at the concentration of $2000 \mu \mathrm{g}$.

Table no: 2. Anti-bacterial activity of Vazhaikizhangu neer- Zone of Inhibition (mm)

\begin{tabular}{|c|c|c|c|}
\hline \multicolumn{4}{|c|}{ 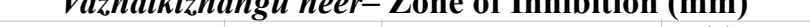 } \\
\hline $\begin{array}{l}\text { Bacterial } \\
\text { Strains }\end{array}$ & $\begin{array}{l}\text { Concen } \\
\text { tration }\end{array}$ & $\begin{array}{c}\text { Sample B } \\
\text { (Vazhaikizhangu } \\
\text { neer) }\end{array}$ & $\begin{array}{c}\text { Chloram } \\
\text { phenicol } \\
(10 \mu \mathrm{g})\end{array}$ \\
\hline \multirow{2}{*}{ E.Coli } & $1000 \mu g$ & 14 & \multirow{2}{*}{14} \\
\hline & $2000 \mu g$ & 14 & \\
\hline \multirow{2}{*}{$\begin{array}{c}\text { Pseudomonas } \\
\text { aruginosa }\end{array}$} & $1000 \mu \mathrm{g}$ & - & \multirow{2}{*}{11} \\
\hline & $2000 \mu \mathrm{g}$ & 9 & \\
\hline \multirow{2}{*}{$\begin{array}{c}\text { Proteus } \\
\text { mirabilis }\end{array}$} & $1000 \mu \mathrm{g}$ & - & \multirow{2}{*}{14} \\
\hline & $2000 \mu \mathrm{g}$ & - & \\
\hline \multirow{2}{*}{$\begin{array}{c}\text { Klebsiella } \\
\text { pnemoniae }\end{array}$} & $1000 \mu \mathrm{g}$ & 10 & \multirow{2}{*}{12} \\
\hline & $2000 \mu \mathrm{g}$ & 14 & \\
\hline
\end{tabular}

Table no: 3, Anti-microbial effect of Amuri and Vazhai Kizhangu Neer

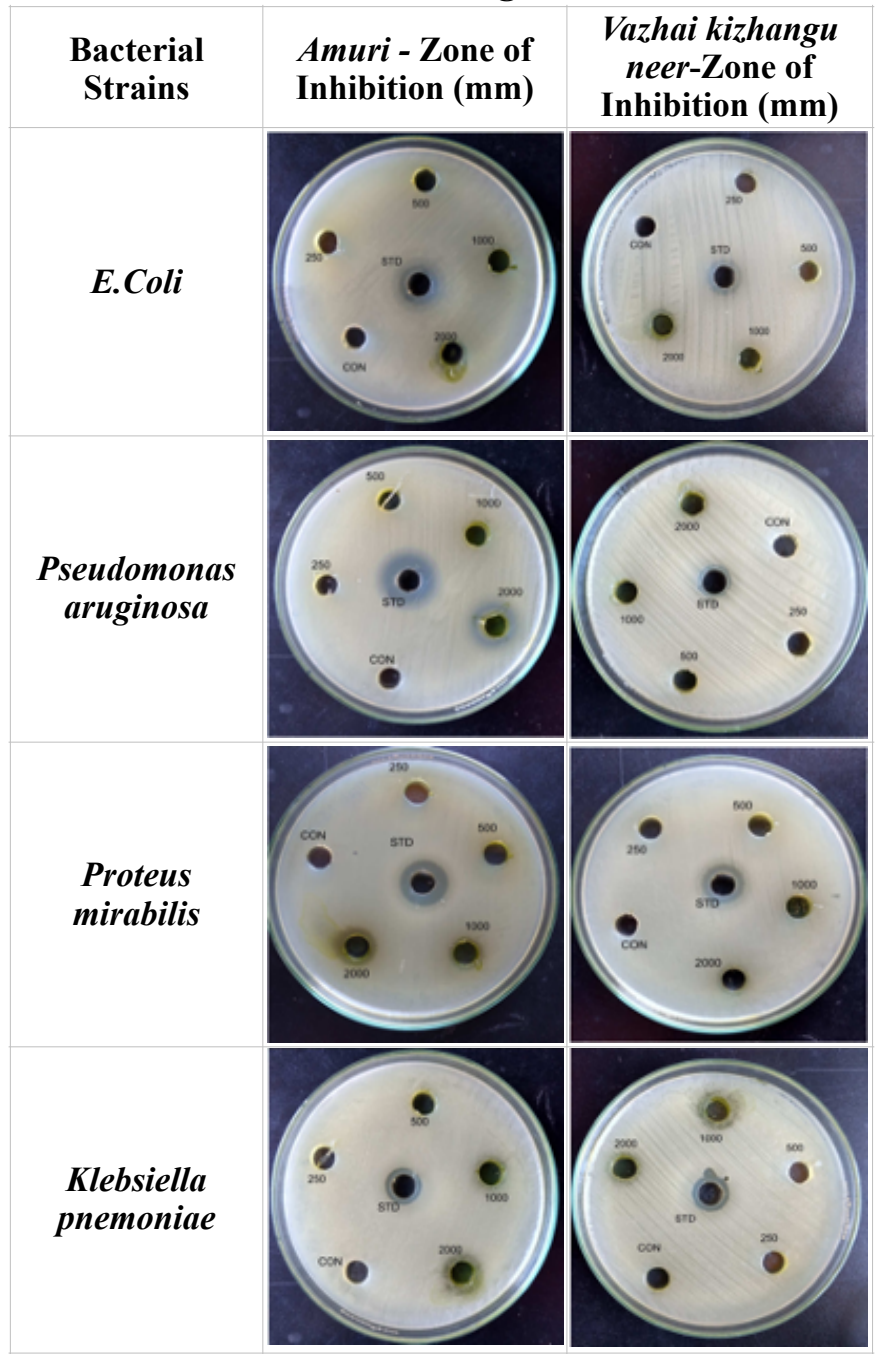

Nowadays resistance to the antibiotics in urinary tract infection is making trouble to control the recurrence of the disease which leads to Multi-Drug Resistance (MDR) and normal intestinal and vaginal flora dysbiosis (6). Several groups of people such as diabetic patients, 
catheterized patients, patients with spinal cord injury, renal transplant patients are at high risk for developing UTI. A retrospective review of 70 patients with renal or peri-renal abscesses over a period of 10 years summarized that $62 \%$ were diabetic in which the isolated organisms were $E$. coli and Klebsiella pneumoniae (7). Antibiotic resistance and their harmful effects drive the people to approach the natural remedies to maintain their immune status balanced.

In this study, traditionally prepared Amuri gained by treating with Guru chunnam exhibit higher inhibitory growth on all tested bacterial strains E.coli, Proteus mirabilis, Pseudomonas aeuriginosa and Klebsiella pneumoniae. Some studies stated that the traditional herbo mineral drug Thurusu thaivelai karukku acts against specific microbe Pseudomonas aeruginosa (8). Another research study reported the good bactericidal activities of copper sulfate against Proteus vulgaris and Staphylococcus aureus (9).The previous studies about the Thurusu (Copper sulphate) on antimicrobial activity strongly suggests the good antibacterial potency of Amuri (sample A) .

The consumption of Vazhai kizhangu neer / Vazhai kattai neer is the effective treatment in conventional UTI therapies. The vazhai kizhangu neer (sample B) also demonstrated its antimicrobial activity on E.coli, Pseudomonas aeuriginosa and Klebsiella pneumoniae.

Earlier in-vitro antimicrobial effect of crude extract of Musa paradisiaca Linn showed the inhibitory effect on bacteria Escherichia coli, Staphylococcus aureus, Bacillus subtilis, Pseudomonas aeruginosa and fungi Candida albicans, Candida tropicalis and Aspergillus niger (10). Three banana plant parts (corm, pseudo stem and leaves) were evaluated for their antibacterial activity against Bacillus cereus, Micrococcus luteus, Staphylococcus aureus, Streptococcus faecal (all Gram-positive), Aeromonas hydrophila, Escherichia coli, Salmonella enterica sub sp. enterica and Shigella sonnei (all Gram-negative), one fungi Candida albicans, showed $>50 \%$ of growth inhibition (11). Different Musa species leaf extracts of Musa acuminata, Musa troglodytarum, Musa sapientum and Musa paradisiaca were investigated for antibacterial activity against multi-drug resistant pathogens (E. coli, P.aeruginosa and Citrobacter species) causing nosocomial infection by agar well diffusion method (12).

Scientific evidence establishes the antibiotic properties of various Musa species. Moreover it is easily access to the public for its cost effectiveness and ready availability. The both samples from plant extract potentially effective in suppressing microbial growth of urinary tract infection bacteria with variable potency. Sample A (Amuri) suppressing microbial growth of all tested bacterial strains followed by sample B (Vazhai Kizhangu neer) which appear to be potentially effective against four bacterial strains and less effective against Proteus mirabilis.

\section{Conclusion}

The present anti-microbial study results revealed that, the both samples of Amuri and Vazhai kizhangu neer have been proved as a potent agent against the common urinary pathogens and concluded that the test drugs can be used for the treatment of urinary tract infection. Further studies to be needed on the yield of Amuri and its pharmacological actions.

\section{Acknowledgement}

The authors acknowledge with thanks for the support provided by the National Institute of Siddha to carry out this work.

\section{References}

1. Waller Et.al, Urinary Tract Infection Antibiotic Resistance in the United States. Primary Care: Clinics in Office Practice, 2018, 45(3), 455-466.

2. TKN Siddha Ayurveda Vaidhayashala, October 7, 2016, Siddha Medicine Blogs.

3. Sudha R et.al Amuri an elixir from Musa paradisiaca Linn Linn, Indian Journal of Traditional Knowledge,April 2004, vol3 (2), pp 168 -176.

4. Murugesa muthaliyar, Gunapadam First part Mooligai, Indian Medicine and Homeopathy, 2013.

5. Marimuthu Revathi Et.al, screening of antimicrobial activity of Siddha drug kukkiladhi choornam, Hygeia.J.D.Med. August 2018; 10 (1); 40-42

6. Das, Sarita, Natural therapeutics for urinary tract infections-a review. Future Journal of Pharmaceutical Sciences. 2020; 6(1): 64

7. Shu T, Green JM, Orihuela E. Renal and perirenal abscesses in patients with otherwise anatomically normal urinary tracts. J Urol. 2004 Jul; 172(1):148-50.

8. Arunvanan $M$ et.al, Anti- microbial activity of "Thurusu thaivelai karukku" in the management of respiratory diseases, Int J Pharm Pharm Sci, January 2012; Vol 4(2), 10-11.

9. Benhalima L, Amri S, Bensouilah M, Ouzrout R. Antibacterial effect of copper sulfate against multidrug resistant nosocomial pathogens isolated from clinical samples. Pak J Med Sci. 2019, Sep-Oct; 35(5);1322-1328.

10. Karadi, Ravindra \& Shah, Arpan \& Parekh, Pranav \& Azmi, Parvez. Antimicrobial Activities of Musa paradisiaca Linn Linn and Cocos nucifera. International Journal of Research in Pharmaceutical and Biomedical Sciences. (2011);2(1); 264-267.

11. Jouneghani RS, Castro AHF, Panda SK, Swennen R, Luyten W. Antimicrobial Activity of Selected Banana Cultivars Against Important Human Pathogens, Including Candida Biofilm. Foods. 2020 Apr 4; 9(4):435.

12. Karuppiah P, Mustaffa M. Antibacterial and antioxidant activities of Musa sp. leaf extracts against multidrug resistant clinical pathogens causing nosocomial infection. Asian Pac J Trop Biomed. 2013 Sep; 3(9); 737-42. 